\title{
Gender Under Incomplete Acquisition: Heritage Speakers' Knowledge of Noun Categorization
}

\section{Citation}

Polinsky, Maria. 2008. Gender under incomplete acquisition: Heritage speakers' knowledge of noun categorization. Heritage Language Journal 6(1): 40-71.

\section{Published Version}

http://www.heritagelanguages.org/

\section{Permanent link}

http://nrs.harvard.edu/urn-3:HUL.InstRepos:3382970

\section{Terms of Use}

This article was downloaded from Harvard University's DASH repository, and is made available under the terms and conditions applicable to Open Access Policy Articles, as set forth at http:// nrs.harvard.edu/urn-3:HUL.InstRepos:dash.current.terms-of-use\#OAP

\section{Share Your Story}

The Harvard community has made this article openly available.

Please share how this access benefits you. Submit a story.

Accessibility 


\title{
Gender under incomplete acquisition: Heritage speakers' knowledge of noun categorization*
}

\author{
Maria Polinsky \\ University of California, San Diego
}

\section{Introduction}

Incomplete competence in first language is an intriguing problem, one that subsumes interrupted acquisition, delayed acquisition, and language loss. Incomplete or interrupted acquisition is represented by heritage speakers, who only recently have been recognized as a group separate from those bilinguals for whom one of the languages is strongly dominant. In the last decade, heritage speakers have come to the fore in a number of fields, from language teaching (Kagan and Dillon 2001, Bermel and Kagan 2000, Geisherik 2005) to soiciolinguistics (Andrews 1998, Fenyvesi 2005, Seliger and Vago 1991, among many others) to general linguistics (Dorian 1989, Seliger and Vago 1991) and psycholinguistics (Sorace 2004, Tsimpli et al. 2004). Understanding the nature of incomplete acquisition is crucial for our understanding of acquisition, and it is fair to say that heritage speakers provide a crucial missing link between competent L1 learners, balanced bilinguals, and possibly L2 learners. Since very little is actually known about heritage language speakers, studying different aspects of language structure in this population is important. In addition to the challenge of uncovering descriptive generalizations needed to understand incomplete acquisition, the heritage population poses another challenge to language researchers: it is not always clear how to assess what it is that heritage speakers do and do not know in

\footnotetext{
* This paper arose from my earlier work on gender categorization and gender priming in the Russian spoken by baseline speakers. Part of that work was done with Liz Bates, who is sorely missed. I am grateful to David Andrews, Nicoleta Bateman, Suzie Bauckus, Shannon Casey, Soonja Choi, Bernard Comrie, Grev Corbett, Grant Goodall, Jay Jasanoff, Olga Kagan, Tracy Holloway King, Robert Kluender, Katya Protassova, and Yakov Testelets for helpful discussions of this project. Comments by two anonymous reviewers are also gratefully acknowledged. All errors are of course my responsibility.
}

This paper would not have been possible without the participation of the American Russian speakers-they are much more than just the initials and numbers used to code them, and it is hard for me to think of them as mere subjects for the experiments. This work was supported in part by the University of California Academic Senate grant and grants from the Dean of Social Sciences at UCSD. 
their first language, so developing replicable methodology of language investigation is also crucial for heritage language studies as a field.

These are general, overarching goals. This paper does not achieve them once and for all; rather, it attempts to address these goals on a smaller scale, in addressing a particular grammatical phenomenon in a single heritage language. In what follows, I will present and discuss a study of gender assignment (noun categorization) in heritage Russian and in doing so will also attend to critical issues in the methodology of heritage language study. To anticipate the conclusions of this paper, the gender assignment data presented here argue for the systematicity of the system that emerges under incomplete acquisition. The system is different from its correspondent system in the baseline, but it is still coherent, albeit in its own way. Another general point that this paper makes is that by using simple experimental methodology, we can obtain crucial linguistic data on incomplete acquisition.

Let me start by defining the crucial notions in a more precise way. An incomplete learner or heritage speaker of language $\mathrm{A}$ is an individual who grew up speaking (or only hearing) A as his/her first language but for whom A was then replaced by another language as dominant and primary. It is important to bear in mind that heritage speakers are not a homogeneous group, but rather form a cline of those who may only understand the language ("overhearers" - cf. Au and Romo 1997, Au and Oh 2005) to very advanced heritage speakers who may simply miss some registers in their language (groups III and IV in Bermel and Kagan 2000). Understandably, much pedagogical effort has been directed at the more proficient heritage speakers (Valdes 2001, Bermel and Kagan 2000, etc.); from the developmental standpoint, the less proficient groups may be equally interesting though. The baseline language for a heritage speaker is the language that $\mathrm{s} /$ he was exposed to as a child. Since heritage speakers are typically not exposed to the language norm through formal schooling, the baseline should not be identified with the standard language available to fully competent speakers of A. For instance, it would be unrealistic to expect those who grow up as heritage speakers of northern Mexican Spanish to have even rudimentary knowledge of Iberian Spanish or more standard dialects of Mexican Spanish.

With these notions now clarified, let us turn to the primary focus of this paper: gender assignment on nouns in heritage speakers of Russian whose dominant language is (American) English. Such speakers are often referred to as American Russians, and like heritage speakers of other languages, they are 
known to form a fairly heterogeneous group, which already poses challenges for a uniform investigation designed to come up with a one-size-fits-all set of generalizations. In this study, the focus is on those speakers who rank quite low on the proficiency scale, and they were selected for a number of reasons. First, assuming that incomplete acquisition is a phenomenon that needs to be distinguished from bilingualism, lower proficiency heritage speakers provide the most promising way to determine if the distinction is real, not imaginary. In these speakers, whatever is present can be taken as representative of incomplete acquisition per se, and the differences from the baseline can also be expected to be more pronounced. Second, the notorious difficulties in production of lower proficiency heritage speakers pose interesting practical challenges, forcing researchers to look for new methodologies of assessing control of the heritage language.

The reasons for studying gender assignment under incomplete acquisition are also quite compelling. First of all, since almost everything in incomplete acquisition is uncharted territory, a systematic investigation of individual grammatical phenomena is of the essence. Noun categorization is a fascinating phenomenon which brings together morphology, phonology, syntax, and simple semantic structures, so understanding categorization in a particular language offers us a glimpse into several levels of linguistic representation. Noun categorization provides a window on both lexical access (which is one of the primary motivations for categorization - cf. Levelt 1989, 1993) and sentence processing, where the knowledge of a relevant noun class contributes to reference identification and tracking. Russian offers interesting opportunities to investigate the functional contribution of gender information to lexical access, because of its three-gender system with complex interactions between gender (an inherent property of nouns) and case (a property of nouns determined by the structure of the sentence), as well as its substantial word order variation. The second reason is less apparent and has to do with the established differences between L1 and L2 learning of gender (Karmiloff-Smith 1979; Sokolik and Smith 1992; Carroll 1989, 1995). Building on these findings, we can use the knowledge of gender assignment in heritage speakers to compare them to both competent baseline speakers and L2 learners.

With this general overview as the background, the rest of the paper is structured as follows. Section 1 provides a bird's eye view of Russian gender, including the discussion of gender errors in L1 learners. Section 2 presents a production experiment design to investigate gender assignment in heritage speakers 
of Russian (American Russian speakers). Section 3 presents a follow up experiment aimed at comprehension. Conclusions and outstanding questions are summarized in section 4.

\section{Gender assignment in Russian.}

\subsection{General principles}

To understand the discussion below, a brief overview of the Russian gender system is required (for details, see Corbett 1991: 34-43; Comrie et al. 1996: 104-117, and further bibliography there). Russian has three genders: masculine, feminine, and neuter. Masculines constitute about $46 \%$ of the nominal lexicon, feminines $41 \%$, and neuters $13 \%$. Grammatical gender is correlated with semantic gender in the usual way, but there are many exceptions as a function of both declensional type and phonological factors (especially noun ending).

The system of gender assignment is intrinsically linked to declensional class, hence it requires access to the endings in the unmarked case (nominative) as well as additional declensional information. To anticipate the results for American Russian, it is precisely the loss of declensional classes that leads to a significant reanalysis of gender assignment, so the link between declension and gender is extremely important.

Baseline Russian has at least six noun cases (nominative, accusative, dative, genitive, instrumental, and locative, cf. Zaliznjak 1967), organized into several declensional classes, shown in Table 1.

Table 1. Main declensional classes in Russian (singular only)

\begin{tabular}{|l|l|l|l|l|}
\hline & Class I & Class II & Class III & Class IV \\
\hline & 'city' & 'water' & 'mud' & 'milk' \\
\hline Nominative & gorod & voda & grjaz' & moloko \\
\hline Accusative & gorod & vodu & grjaz' & moloko \\
\hline
\end{tabular}




\begin{tabular}{|l|l|l|l|l|}
\hline Dative & gorodu & vode & grjazi & moloku \\
\hline Genitive & goroda & vody & grjazi & moloka \\
\hline Instrumental & gorodom & vodoj & grjaz'ju & molokom \\
\hline Locative & gorode & vode & grjazi & moloke \\
\hline
\end{tabular}

Corbett (1991: 34-43) has developed an explicit algorithm of gender assignment, which is reproduced here. Aside from the small semantic core (1), the rest of the Russian nouns are assigned gender on the basis of formal information, as shown in Figure 1.

(1) Russian noun categorization: Semantic core

a. sex-differentiable nouns denoting human and higher animal males are masculine

b. $\quad$ sex-differentiable nouns denoting human and higher animal females are feminine

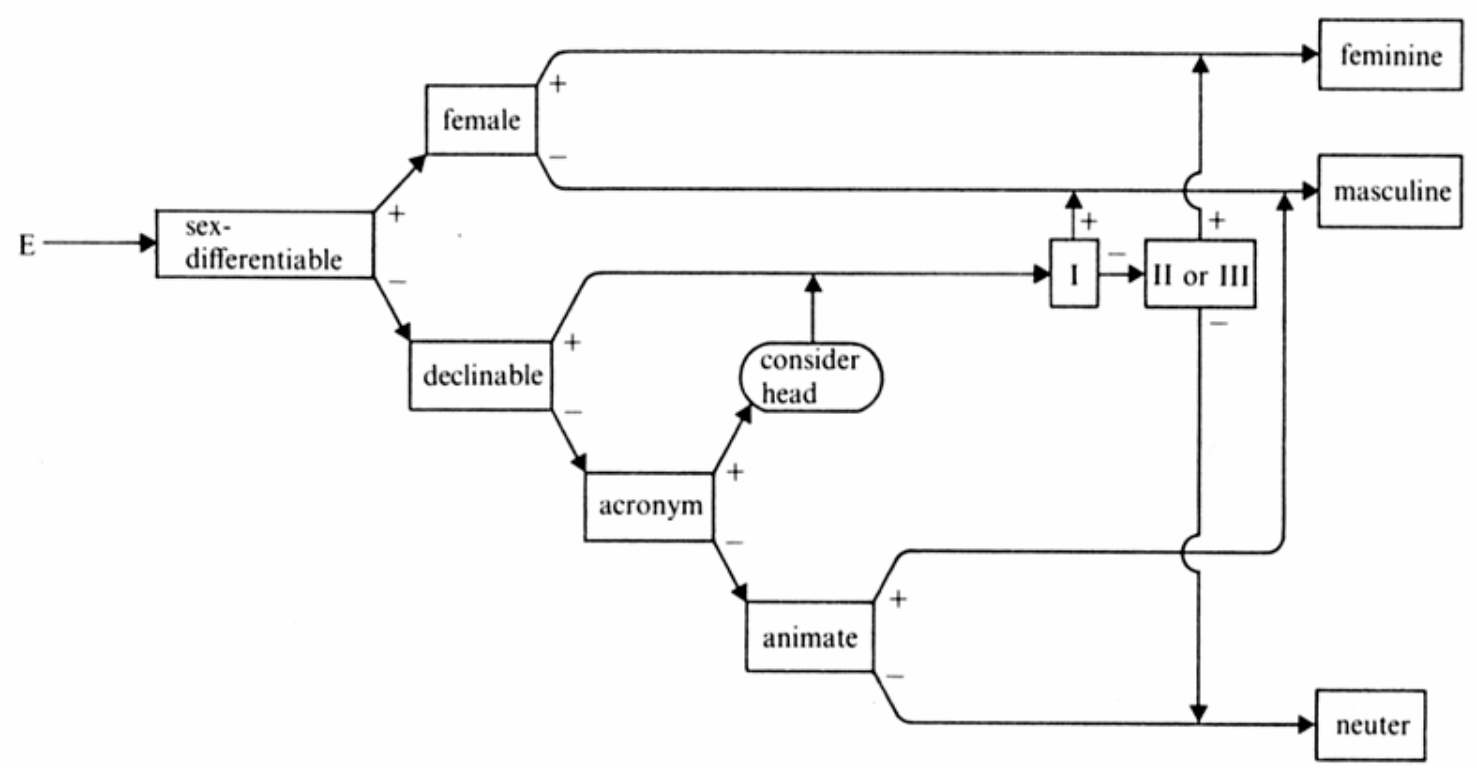

Figure 1. Gender assignment in Russian (from Corbett 1991: 41)

Gender agreement is manifested on adjectives, participles, demonstratives, possessive pronouns, past tense verbs, and some numerals, as illustrated in Table 2. 
Table 2. Gender agreement in Russian

\begin{tabular}{|l|l|l|l|}
\hline & Past tense verb & Adjective & Possessive pronoun \\
\hline & pada- 'fall down' & star- 'old' & $\begin{array}{l}\text { tvo- 'your(s)' } \\
(2 \text { sg.poss })\end{array}$ \\
\hline Masculine & padal- $\varnothing$ & star-yj & tvo-j \\
\hline Feminine & padal-a & star-aja & tvo-ja \\
\hline Neuter & padal-o & star-oje & tvo-jo \\
\hline Plural (neutralized form) & padal-i & star-yje & tvo-i \\
\hline
\end{tabular}

The agreement trigger can either follow or precede its probe (the constituent whose agreement features match those of the trigger); as is evident from table 2, agreement is signaled by modifier endings. For adjectives and demonstratives, which will feature prominently in the experiments below, the pronunciation of these endings is dependent on the stress of a given lexical item (Russian has mobile stress).

In the baseline pronunciation of Russian, adjectives/demonstratives that are stressed on the stem rather than the ending do not distinguish between feminine and neuter, e.g. for the adjective 'main' and demonstrative 'this':
(2) a. masculine: glavnyj [glávnyj]/ètot [æt $\Lambda \mathrm{t}]$
b. feminine: glavnaja [glávnəjə]/èta [æu $\Lambda$ ]
c. neuter: glavnoje [glávnəjə]/èto [æt $\Lambda$ ]

All noun modifiers have a distinct form for the masculine. Noun modifiers that do not distinguish between feminine and neuter will be referred to below as ambiguous. Modifiers that always distinguish feminine and neuter, by virtue of stress on the ending, will be referred to as unambiguous (Ahutina et al. 2001). Only unambiguous modifiers will be used in the experiments below.

\subsection{Russian gender in uninterrupted acquisition}

Turning now to the acquisition of Russian, not all the issues are quite clear, mainly because all the data come from observation and no experimental work testing language competence has been conducted. 
Based on the detailed observation data, primarily in Gvozdev's work (1961), it seems that for a Russian speaking child, gender assignment is generally correct by 2;5-2;7 (Gvozdev 1961: 216, 441). According to Gvozdev's observations, children have a three-gender system from the early stages of acquisition, recognizing the difference between masculine, feminine, and neuter. ${ }^{1}$ The evidence for noun categorization comes from the correct use of agreeing forms (pre- and postnominal modifiers, past tense verb forms) and the use of gendered pronouns (on, ona, ono). The generalization that gender assignment is linked to the knowledge of declensional classes is indirectly confirmed by the acquisition data: the use of case forms is practically stable by the end of the third year, and most of the cases are used correctly earlier, by the end of the second year (Gvozdev 1961: 382-393).

Three main groups of nouns remain challenging to a monolingual child beyond the third year. These include masculine nouns ending in a vowel (e.g., papa 'daddy') which are occasionally treated as feminine. Such errors seem to be few and far between and they disappear around age 3 . The most persistent errors include the treatment of feminine nouns ending in a palatalized consonant $\left(\mathrm{C}^{\mathrm{j}}\right.$, which appears as C 'in transliteration) as masculine, for example, myš' 'mouse', rož' 'rye', krovat' 'bed'; such errors persist up to the age of 7;9, and, as the examples show, involve both animate and inanimate nouns. Stem-stressed neuter nouns are another source of errors. Here, the child reanalyzes them in two different ways, both consistent with the more general principles of Russian grammar. If the final unstressed vowel of the noun in question is retained, such a noun is treated as feminine, e.g. čudo 'miracle', poleno 'log', ukrašenie 'decoration' (Gvozdev 1961: 442), and the agreeing form reflects that. ${ }^{2}$ The other strategy consists of deleting the final vowel of stem-stressed neuter nouns; the resulting form is then reinterpreted as masculine, e.g. jabloko > jablok 'apple', doloto > dolot 'chisel' (Gvozdev 1961: 442). The major errors in gender assignment are summarized in Table 3. Importantly, all the reinterpretations are in keeping with the general morphophonemic principles of gender assignment; 'problematic'

\footnotetext{
${ }^{1}$ The use of a three-gender system from the early stages is different from the developmental profile of children learning a classifier language, where the initial system includes only a small number of classifiers — a subset of the adult set (Erbaugh 2004, Carpenter 1992 and references therein).

${ }^{2}$ Such neuter-to-feminine reanalysis is also observed in Russian dialects and substandard speech (see Comrie et al. 1996:
} 111). 
declensional classes are either small or call for gender assignment rules that are in conflict with the rules for the other classes. Three difficult classes persist up to age 6-7, at which point it is hard to tell if the relevant genders ultimately get learned in a natural way or are enforced by schooling, where children's errors in gender are corrected in an explicit way (see Comrie et al. 1996: 110-111 for some pedagogical recommendations which suggest implicit problems with the classes discussed here).

Table 3. Gender errors: Monolingual Russian children

\begin{tabular}{|l|l|l|}
\hline Gender in adult language & Re-analyzed as & $\begin{array}{l}\text { Age until which the pattern is } \\
\text { observed }\end{array}$ \\
\hline Masculine, ending in a vowel & feminine & $3 ; 0$ \\
\hline $\begin{array}{l}\text { Feminine, ending in a palatalized } \\
\text { consonant }\end{array}$ & masculine & $7 ; 9$ \\
\hline Neuter, stem-stressed & feminine: final vowel retained & $6 ; 0$ \\
\hline Neuter, stem-stressed & Masculine: final vowel deleted & $6 ; 6$ \\
\hline
\end{tabular}

Now that we have established general principles which govern gender assignment in Russian and have identified sets of nouns which are problematic for gender assignment, we can continue on to the assignment in heritage speakers. Are their problems similar to those of Russian-speaking children? If so, are these speakers just frozen at a relatively early stage of acquisition where they never had a chance to learn the problematic classes? In addition, since heritage speakers do not have schooling in their heritage language they never have a chance to be explicitly corrected on their problematic gender.

\subsection{Gender in American Russian}

There is a compelling reason to expect that American Russian gender assignment is different from that of the baseline - as shown above, gender assignment crucially depends on the knowledge of declensional classes, and declensional classes are generally absent from the American Russian system. Low proficiency heritage speakers typically have two case forms, one unmarked (corresponding to the nominative), the other based on the accusative case (Polinsky 1997, 2000, in press-a). This suggests that the declensional base of gender assignment may be either extremely weak or missing altogether, and may be crucially different from the declensional system of the baseline. As we saw above, the 
declensional system is crucial in providing cues for gender assignment. If this system undergoes change or reanalysis in the heritage language, it is fair to expect that gender assignment rules may change too. As the results reported here show, this is indeed the case.

However, despite significant changes in the declensional system, gender does not disappear from an incompletely learned system but rather undergoes a strong reanalysis. Based on naturally occurring data, American Russian speakers do produce gender-agreeing forms, primarily adjectives and possessive pronouns; however, gender agreement on past tense verbs is often missing (Polinsky 1997, in press-a). Here are some typical examples of gender errors from naturally occurring data (the parentheses show how a particular gender of the baseline was reinterpreted in the heritage language):

(3) moj mat' 'my (masc.) mother' (fem > masc)

(4) moja deduška 'my (fem.) grandfather' (masc $>$ fem)

(5) ètot sol' 'this (masc.) salt' (fem $>$ masc)

(6) moja polotenc[ə] 'my (fem.) towel' (neuter $>$ fem)

Aside from (3), these examples are consistent with the gender errors made by monolingual Russian children that were noted in Gvozdev's study.

Next, American Russian speakers are not always unswerving in gender agreement even within the limits of a single clause. For instance, in (7), an American Russian speaker treats the feminine noun 'car' as masculine for the purposes of verb agreement and as neuter for the purposes of adjectival agreement:

mašina byl bol'šoe

car.fem was.masc big.neuter

'The car was big.'

In translation elicitations, American Russian speakers typically offer the neuter (or neuter/feminine, for ambiguous items) form as the citation form of adjectives (the conventional citation form in the baseline is the masculine). For instance, in translating adjectives from the basic vocabulary list of 200 items, out of 27 adjectives, the majority of adjectival citation forms are in the neuter (neuter/feminine for 
ambiguous items). Table 4 shows the distribution of citation forms for a randomly selected subset of subjects.

Table 4. Citation forms for the adjectives on the 200-word list: Heritage speakers

\begin{tabular}{|l|l|l|l|l|l|}
\hline Adjective & SP & AP & MK & RK & YG \\
\hline bad & N & M & M & F & N \\
\hline cold & NF & Adv & NF & NF & NF \\
\hline correct & $\mathbf{x}$ & M & Adv & M & NF \\
\hline dirty & NF & M & NF & NF & NF \\
\hline dry & N & N & N & N & N \\
\hline dull & $\mathbf{x}$ & M & NF & NF & NF \\
\hline far & Adv & NF & NF & Adv & Adv \\
\hline full & F & M & NF & NF & Adv \\
\hline good & Adv & M & NF & Adv & Adv \\
\hline heavy & NF & M & NF & NF & NF \\
\hline left & Adv & NF & Adv & Adv & NF \\
\hline narrow & NF & M & M & NF & NF \\
\hline near & Adv & M & Adv & Adv & Adv \\
\hline new & NF & NF & NF & NF & NF \\
\hline old & NF & M & NF & NF & NF \\
\hline right & Adv & NF & NF & NF & NF \\
\hline rotten & $\mathbf{x}$ & NF & NF & NF & NF \\
\hline round & NF & M & NF & NF & NF \\
\hline sharp & NF & M & NF & NF & NF \\
\hline short & NF & M & NF & M & NF \\
\hline small & NF & M & NF & NF & NF \\
\hline smooth & $\mathbf{x}$ & M & NF & M & NF \\
\hline straight & Adv & Adv & Adv & Adv & x \\
\hline thick & $\mathbf{x}$ & $\mathbf{x}$ & $\mathbf{x}$ & NF & NF \\
\hline thin & NF & M & $\mathbf{x}$ & NF & NF \\
\hline wet & M & M & N & N & N \\
\hline wide & NF & M & NF & NF & NF \\
\hline & & & & & \\
\hline & & & & \\
\hline
\end{tabular}

Adv: used adverb, F: feminine, M: masculine, N: neuter, NF: neuter/feminine (ambiguous adjectives), $\mathbf{x}$ : no answer

Even if we include translational data like the ones in Table 4, naturally occurring examples make it very hard to arrive at any systematic generalizations. What if all the errors simply result from on-line production problems? After all, American Russian speakers 'in the wild' do not show any serious comprehension problems, which suggests that their gender system is structured adequately enough to permit good understanding. In order to determine if this is really the case, we conducted two 
comprehension experiments involving gender assignment. These experiments are presented in the next section.

\section{Gender assignment in American Russian: Experiment 1.}

So far, one of the most challenging aspects of heritage language studies has been finding the right methodology of investigation. Traditional elicitations of grammaticality judgments have faced significant difficulty, namely that heritage speakers often perform at chance on grammaticality judgment tasks. A more informal observation of naturally occurring data is problematic as well. The actual linguistic production by heritage speakers is often very weak, faltered, and hard to monitor in a consistent way. This leads to significant discrepancies across observational data. Because of wavering production and significant variation across speakers, it has also been difficult to conduct production experiments with heritage speakers as subjects. Even if such experiments were successful they would still beg the question of whether or not production alone could be the Achilles heel of heritage speakers' performance.

All these considerations point to the utility of comprehension studies, and this is what was done in the research presented here. The experiment presented in this section was designed to limit the subjects' production to a minimum and to create a sufficiently constrained experimental setting in which the data from individual subjects could be compared directly.

The general goal of Experiment 1 was to test American Russian speakers' knowledge of gender classification and their use of that knowledge in agreement.

\subsection{Participants, stimuli, procedure}

The participants were twelve American Russian speakers, all of whom self-identified as heritage speakers. All were undergraduates or graduate students at several campuses of the University of California (average age 27). All subjects but three were born in the USA to Russian speaking families, the three Russian-born subjects moved to the USA between ages 3 and 5; according to self-report, they stopped speaking Russian and switched to English around age 4-7 (2 subjects at age 4, 5 subjects at age 5,3 subjects at age 6, and 2 subjects at age 7). None of the participants could read Cyrillic and none had 
taken high school or college classes in Russian. All reported speaking English all the time but understanding Russian when spoken to by family members. All the participants were given a lexical test (200-word list to be translated from English into Russian), were asked a series of personal history questions (cf. the questionnaire in Godson 2003), and were asked to produce a story based on the standard frog-story design (Berman and Slobin 1994). ${ }^{3}$ The controls included five monolingual Russian speakers, average age 33;8 (two subjects who live in Moscow were tested during a visit to San Diego, the three others were tested in Moscow in September 2005).

The stimuli included 122 Russian nouns, all inanimate (Appendix 1). The nouns were selected from the 1,100-2,500 frequency range (based on the frequency data in Sharoff 2001) and balanced by length (average length 5.5 phonemes). No nouns with potential English/Latinate cognates were used. The distribution by gender was as follows: 45 masculine nouns ( 2 nouns ending in $-j)$; 43 feminine nouns ( 8 ending in a palatalized consonant; of the remaining 35, 12 end-stressed); 34 neuter nouns (15 endstressed). The percentage of neuters is slightly higher than would be expected given the 46/41/13 gender ratio in modern Russian. The decision to use more neuters was motivated by the desire to avoid statistical problems that could arise from too small a sample.

The subjects' task was to use an unambiguous adjective bol'̌s- 'big' or possessive pronoun $t v$ - 'your' after they heard a particular noun presented by the experimenter. There was no time limit set on the response, and the subjects were allowed to give no response. Prior to the experiment, the subjects were given a training set of six pairs, thus: stol... bol'šoj 'table... big'; jajco... bol'šoe 'egg... big'; čaška ... bol'šaja 'cup... big'. The stimuli used for the practice trials did not occur in the experimental trials. The testing materials were presented in a random order. Each subject encountered all the stimuli only once, over the course of a single session. The subjects were all tested individually, in a quiet room, with the experimenter recording their responses by hand.

\footnotetext{
${ }^{3}$ Frog stories were elicited for an independent study of narrative structure (Polinsky in press-b, in preparation) and were also used to measure the subjects' speech rate (see below).
} 


\subsection{Results}

No problems were noted in the testing of the five controls, whose responses were all counted and are shown by the data in Figure 2. The negligible deviation is most likely due to the testing setting and the perception of the task as extremely easy (two subjects actually commented on the simplicity of the task).

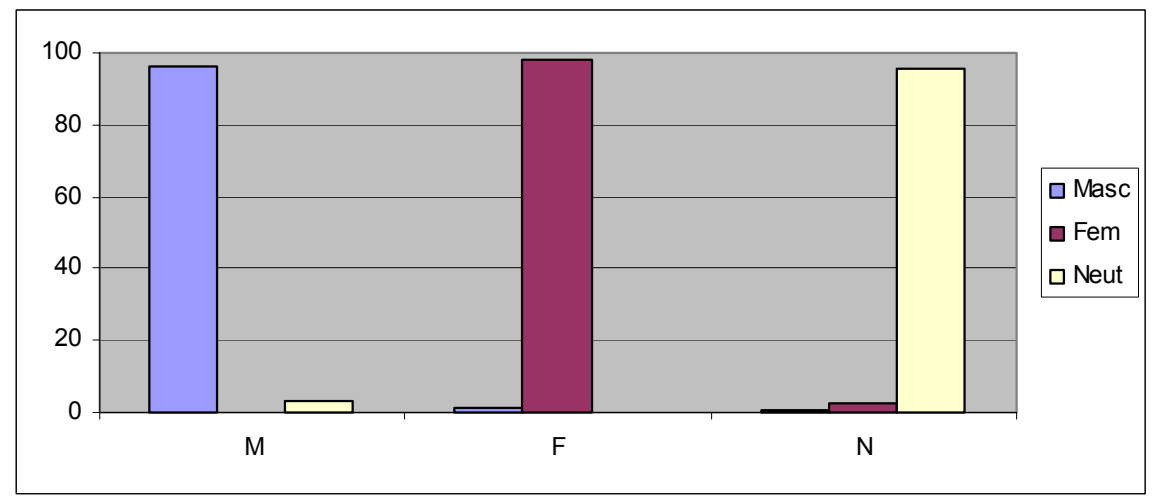

Figure 2. Use of agreeing forms in response to the noun stimuli (N=122, 5 subjects)

Among heritage speakers, one speaker invariably responded with a neuter form, with no differentiation across genders. The data from this speaker were not included. Most subjects left some nouns with no response (no matching adjective or possessive pronoun). There was no correlation between no response and a particular gender, and these data are reflected in the overall statistics. Some speakers offered one gender form first and then changed their response; both responses were recorded.

The results for heritage speakers are summarized in Figure 3. 


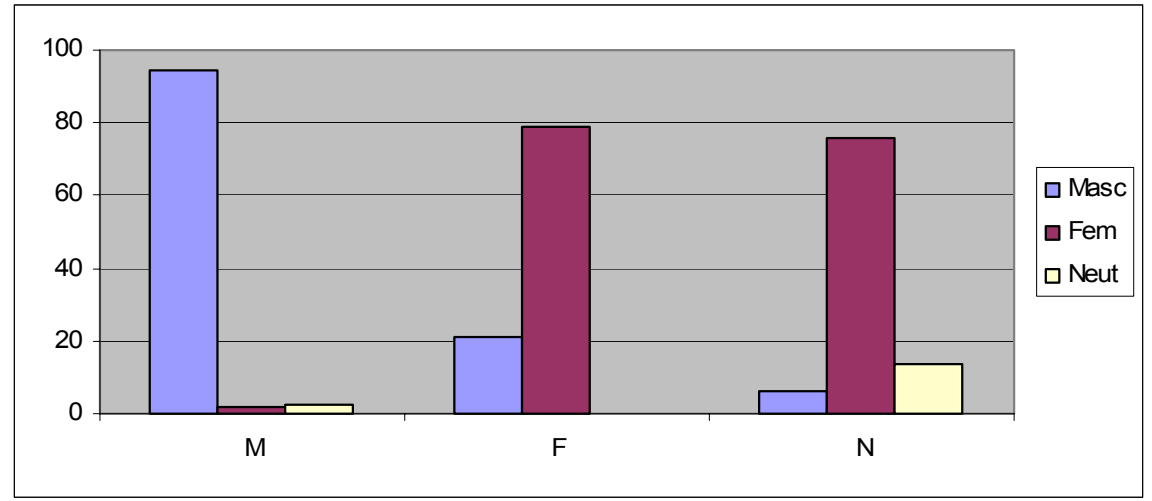

Figure 3. Use of agreeing forms in response to the noun stimuli (N=122, 11 subjects).

The results show that certain noun classes are completely unproblematic for heritage speakers and match the baseline. These classes include masculine nouns (performance on these nouns is close to perfect and does not differ from that of the controls) and feminine nouns ending in a vowel (near-perfect performance). No effect of word stress was found in these classes.

The noun classes that caused problems for heritage speakers include neuters, stem-stressed neuters in particular, and feminines ending in a palatalized consonant. As Table 3 indicates, these classes are also problematic in the course of L1 acquisition of Russian. For the heritage speakers tested, stem-stressed neuters (bolóto 'marsh', vójsko 'army') were treated as feminine nouns, and this pattern was close to categorical. The results are shown in Figure 4. 


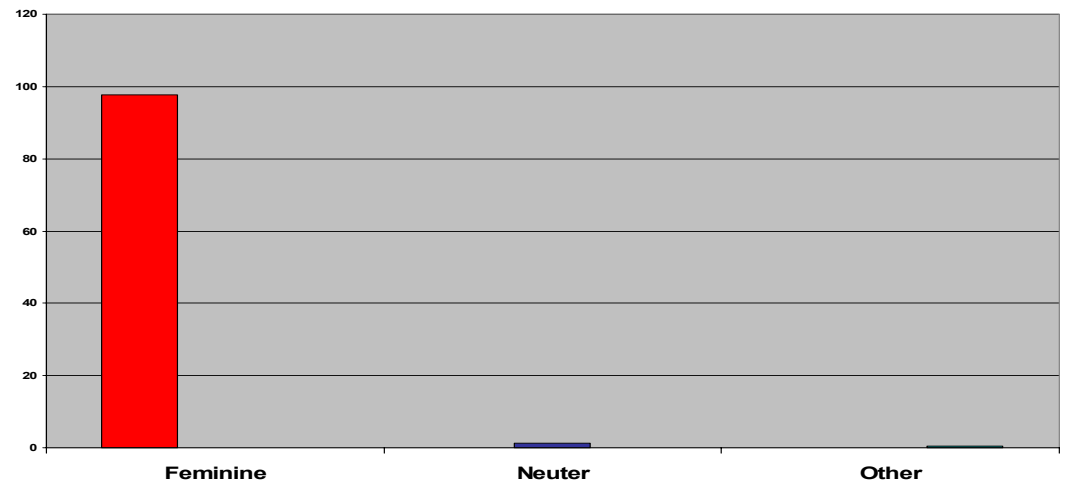

Figure 4. Agreement triggered by stem-stressed neuter nouns, heritage speakers only $(\mathrm{N}=15$, averaged over 11 subjects)

End-stressed neuters (e.g., dnó 'bottom', kryl'có 'porch'), which are more clearly identified as neuter nouns, did not receive a uniform treatment. Some speakers treat them as neuters, while others assimilate them to feminines (occasional masculine agreement was at chance). While variation across subjects was recorded, individual subjects were very consistent with respect to this subclass. I will return to this issue in the discussion subsection below.

The heritage speakers treated feminine nouns ending in a palatalized consonant (e.g., postel' bed', cerkov' 'church') as masculine. Again, as Figure 5 shows, the agreement pattern is close to categorical, with the feminine agreement under $3 \%$. 


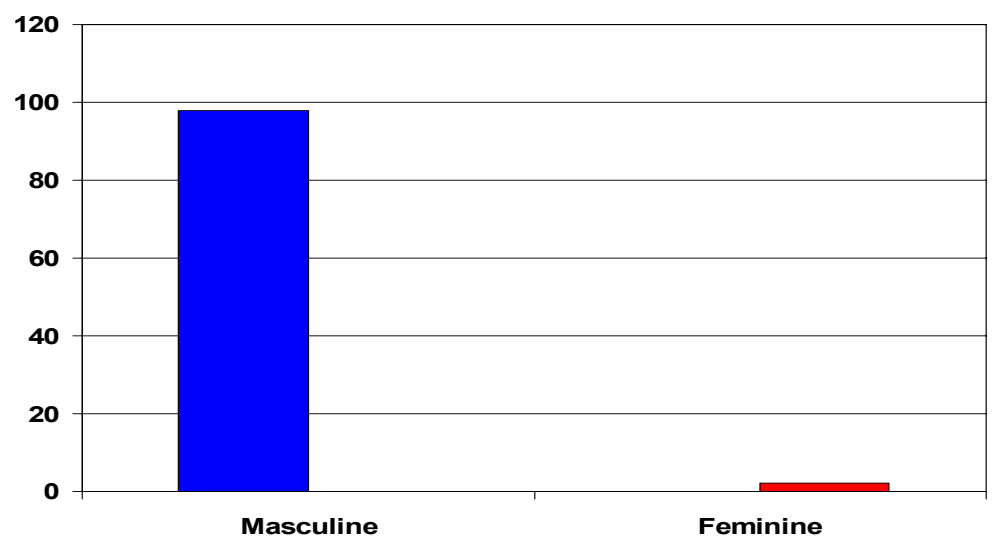

Figure 5. Agreement triggered by feminine nouns ending in a $\mathrm{C}^{\mathrm{j}}$, heritage speakers only $(\mathrm{N}=8$, averaged over 11 subjects)

To summarize, gender assignment in the baseline control group practically mirrors the idealized gender assignment described in grammars of Russian. Heritage speakers perform close to the baseline with respect to masculine nouns and feminine nouns ending in a vowel in the citation form. The problematic classes include neuters, stem-stressed neuters in particular, and feminine nouns ending in a palatalized consonant.

\subsection{Discussion}

The classes that are problematic for heritage speakers are equally problematic in L1 acquisition of Russian. Just like L1 acquirers, heritage speakers assimilate the weaker, less frequent feminine class (Declension III, see Table 2) to the stable masculine class, based on formal analogy. A similar process of analogy may play a role in the heritage speakers' treatment of stem-stressed neuters. These neuter nouns are assimilated to feminine nouns ending in a vowel, and since the latter class is rather large and completely unproblematic, the smaller class of stem-stressed neuters no longer warrants a special status and gets absorbed into the feminine class. The majority of feminine nouns end in a stressed $-a$ or a reduced vowel (typically schwa); stem-stressed neuters also end in a reduced vowel, which provides the basis for an easy assimilation. Unlike L1 learners however, heritage speakers do not show any 
assimilation of stem-stressed neuters to the masculine - such assimilation would require the deletion of the final vowel. Although this is just an isolated data point, it suggests that baseline L1 acquisition and heritage language may face different challenges and it would be premature to think of heritage speakers as simply fossilized L1 learners who never made it to the adult level.

End-stressed neuters, however, have a different final vowel (stress-bearing -o), which can potentially inhibit the assimilation into the feminine class. As was mentioned above, the results for end-stressed neuters are not uniform: some subjects do assimilate them to the feminine class, while others maintain them as a separate class. An intriguing question of course is whether or not the strategy with respect to these nouns is correlated with any other properties of individual performance by heritage speakers. We did find a significant correlation between the treatment of end-stressed neuters and the speech rate, which was measured in a pretest (based on the subjects' presentation of the frog story, elicited in the pre-test). In general, heritage speakers show significant individual variation in speech rate, from the rate rather close to the baseline, to the rates that are three times slower than the baseline. This is illustrated in Figure 6, which shows data for a particularly "slow" speaker (BL) and a speaker closer to the baseline (AR). The individual variation in subjects' rate in English is much narrower - as Figure 6 shows, AR and BL have very similar speech rates in English and both are actually a little faster than a monolingual English baseline speaker. ${ }^{4}$ This indicates that low speech rate in heritage speakers does not correlate with their rate in English.

\footnotetext{
${ }^{4}$ The apparent differences between English and Russian speech rates are naturally due to the difference in word length across the two languages (Russian words are much longer than those in English). However, the important point is to compare the speech rate of a heritage speaker to the speech rate of the baseline, not so much across languages.
} 


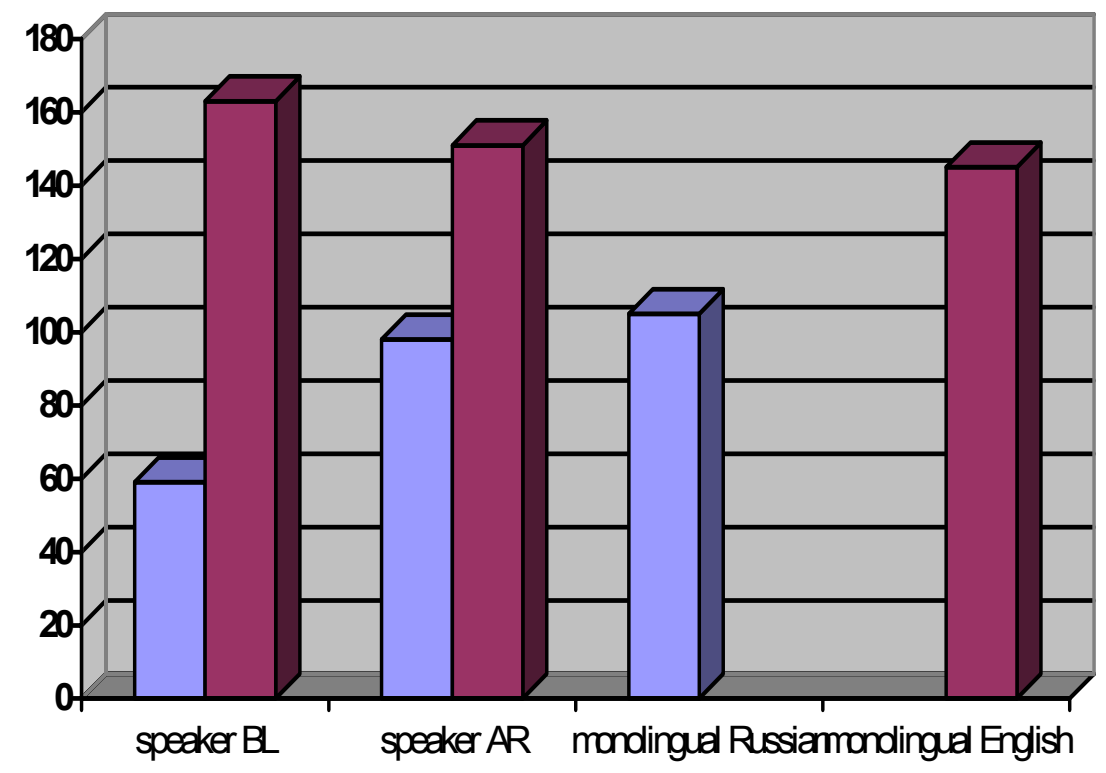

\section{Drate in Russian \\ DrateinEnglish}

Figure 6. Average speech rate in American Russian, baseline Russian, English spoken by American Russians, and monolingual English (frog story narrative, words per minute)

Those heritage speakers whose speech rate is higher (hence closer to the speech rate of the control group and also to their own speech rate in English) maintained the neuter class if only for stem-stressed neuters. Those heritage speakers whose speech rate in Russian was significantly lower than the baseline (and their own rate in English) invariably assimilated the neuter nouns to the feminine class. The averages on speech rate are shown in Figure 7. 


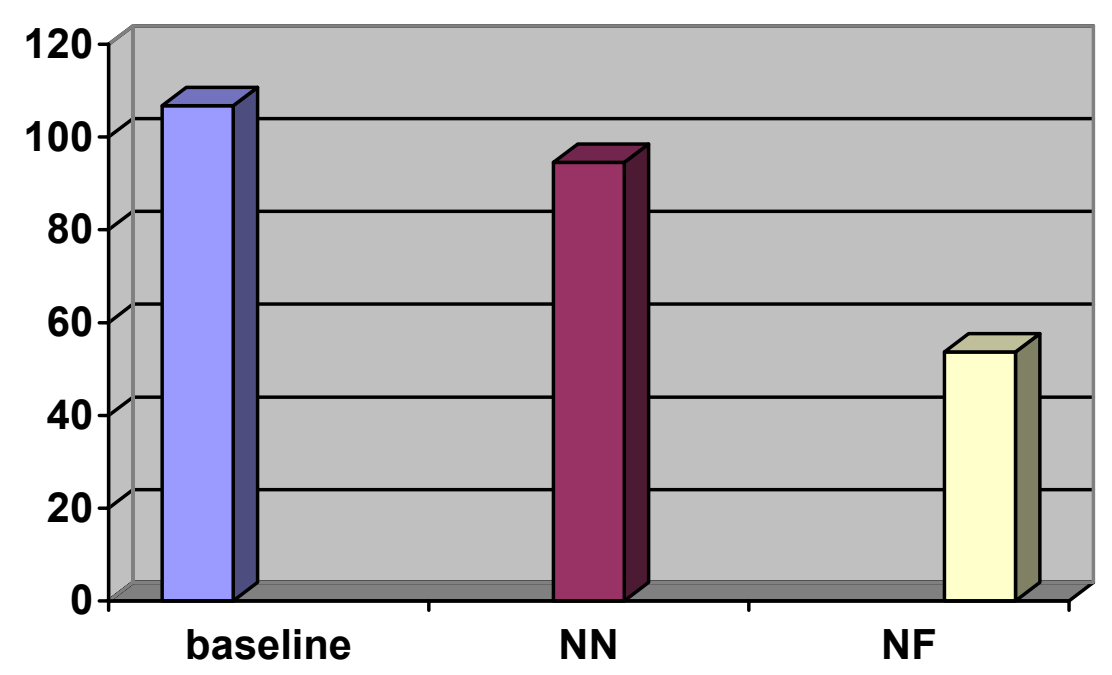

Figure 7. Rate of speech (wrds/min) in baseline controls, speakers who maintained end-stressed neuters $(\mathrm{NN})$, and speakers who treated all neuters as feminines (NF)

The heterogeneity of heritage speakers as a group has long been noted. It constitutes a significant challenge both for research on incomplete acquisition and for language instruction designed for heritage speakers. Speech rate seems to emerge as one of the most sensitive measures reflecting the level of proficiency of a heritage speaker (Kagan and Friedman 2003) and it seems to correlate with the proximity of a particular speaker to the baseline (Polinsky in press-b). Thus, although still heterogeneous, American Russian speakers fall into two predictable groups: more proficient speakers and less proficient ones. More proficient speakers seem to have less of a problem with lexical access and general construction of the clause. This in turn accounts for a faster speech rate. Speakers who are less proficient are naturally hindered in their lexical access, which slows down their utterance (without necessarily being the only reason for slow speech rate). ${ }^{5} \mathrm{An}$ independent measure shows that lexical proficiency in heritage speakers correlates with their grammatical proficiency: the higher lexical proficiency, the closer are heritage speakers to the baseline in terms of grammatical knowledge (Polinsky 1997).

\footnotetext{
${ }^{5}$ Potentially, speakers' performance could be measured using median length per utterance (MLU). However, since heritage speech is characterized by excessive pausing and a high number of sentence fragments, it is rather difficult to establish the limits of an utterance. In this context, the rate of speech measured in words per minute seems to emerge as a more objective measure.
} 
Assuming that the rate of speech correlates with the actual level of proficiency in heritage speakers, we can now use this generalization to interpret the results concerning gender assignment. All heritage speakers are different from the baseline in their treatment of noun classes, but some speakers are more different than others. It seems that maintaining a three-gender system is closer to the baseline (which also distinguishes three genders), while a two-gender system can be indicative of a more radical reanalysis of the system. Speakers who stay closer to the baseline have a higher speech rate and still maintain three classes, while those speakers who completely absorb neuter nouns into the feminine class are further away from the baseline and accordingly, much slower.

Regardless of the final system, the principles used to assign nouns to classes are quite different from the baseline in all heritage speakers. The original intuition, that with the loss of declensional classes gender assignment will have to be based on different principles, has been proven correct. ${ }^{6}$ With no information on declensional classes, heritage speakers assign gender based on the ending of the citation form. Thus the ending available from a single form of a particular word becomes the sole predictor of gender. The relevant rules in both groups can be summarized as follows:

(8) Three gender-system ( $\sim$ more proficient speakers):

a. nouns ending in a consonant are masculine

b. nouns ending in a stressed $-O$ are neuter

c. all other nouns are feminine

(9) Two-gender system ( less proficient speakers):

a. nouns ending in a consonant are masculine

b. nouns ending in a vowel are feminine

As Figure 7 shows, the actual restructuring of the baseline gender system correlates with the proficiency of individual subjects as measured by their rate of speech. It remains to be seen if the proposed

\footnotetext{
${ }^{6}$ In theory, it could have been equally possible to predict that heritage speakers lose gender classes altogether, but this does not happen. I cannot speculate why this scenario does not occur.
} 
breakdown of heritage speakers into overhearers, intermediate and more advanced speakers (Au and Romo 1997, Au and Oh 2005) can be correlated with these results - based on personal history data for our subjects we did not find such a correlation in this study, but further research is needed to examine it.

Overall, heritage speakers have difficulty with the same classes as uninterrupted L1 learners. In standard acquisition, the large amount of declensional information seems to finally trump the errors. In incomplete acquisition, under severely limited input, no such information is available, and the assignment rules have to be generalized over a different set of data. However, the system manifested by heritage speakers is different from that of L1 learners. First, no children learning Russian have been reported to have a two-gender system at any stage. Second, the reanalysis of neuter in both groups $((8)$ and (9)) differs from what is found in child language - while children vacillate between neuter-tomasculine and neuter-to-feminine reanalysis, heritage speakers completely lack the former.

In summary, the experimental results suggest that the category of gender is still fully represented in the grammar of American Russian, but its actual structuring undergoes a significant reanalysis. While gender assignment principles manifested in agreement are different from the baseline, they are definitely not random.

\section{Gender assignment in American Russian: Experiment 2.}

While Experiment 1 tested heritage speakers' knowledge of gender under limited production, the goal of Experiment 2 was to assess this knowledge using comprehension alone. The underlying assumption of this experiment has been mentioned above: what if the differences from the baseline that transpire in a comprehension study are simply due to on-line production problems faced by heritage speakers? In that case, comprehension of heritage speakers should be close or equal to that of baseline speakers. In addition to testing gender assignment in comprehension, this experiment also pursued a methodological goal, that of determining what kinds of experimental measures work best for heritage speakers.

\subsection{Participants, stimuli, procedure}

The participants were twelve American Russian speakers (the same group as the participants in Experiment 1, which was conducted prior to Experiment 2). The controls included ten monolingual 
Russian speakers, average age 38.5 (all speakers either visited California on a trip from Russia or had lived in California for less than one year); three of these speakers were the same as in Experiment 1.

The stimuli (given in Appendix 2) included 45 inanimate nouns, 15 for each gender, selected from the 2,500-4,500 frequency range (based on the frequency data in Sharoff 2001) and balanced by length (average length 6.2 phonemes). The frequency range was below the range used in Experiment 1. No nouns with potential English/Latinate cognates were used. In this group of nouns, it was much harder to keep all the stimuli morphologically indivisible, so them are [there is something missing here - I'm not sure my correction is what you really want to say] only about half of them are clearly monomorphemic, but synchronically they are all treated as unsuffixed. Of the 15 masculine nouns, three nouns end in $-j$; of the 15 feminine nouns, five end in a palatalized consonant, thus representing declensional class III; and of the 15 neuter nouns, six bear end-stress.

To prepare the stimuli, each noun was recorded accompanied by an unambiguous adjective in the feminine, masculine, and neuter. Thus, subjects encountered each noun three times, once in the gendermatching condition, and twice in the gender-incongruous condition, as shown in Table 5:

Table 5. Examples of stimuli used in Experiment 2

\begin{tabular}{|l|l|l|}
\hline & Gender matching condition & \multicolumn{2}{|l|}{ Incongruous condition } \\
\hline masculine (dostatok 'wealth') & bol'šoj dostatok 'big' \\
\hline feminine (krapiva 'nettles') & bol'šaja krapiva & $\begin{array}{l}\text { bol'šaja dostatok } \\
\text { bol'šoje dostatok }\end{array}$ \\
\hline neuter (doloto 'chisel') & bol'šoje doloto & $\begin{array}{l}\text { bol'šoj krapiva } \\
\text { bol'šoje krapiva }\end{array}$ \\
& $\begin{array}{l}\text { bol'šoj doloto } \\
\text { bol'šaja doloto }\end{array}$ \\
\hline
\end{tabular}

The stimuli were presented randomly using Psyscope (Cohen, MacWhinney, Flatt, and Provost 1993). Participants were tested individually in a quiet room. They were told that they would be presented with a series of pairs of words, one pair at a time, and asked to push a button if the pair they heard was an 
acceptable combination in Russian. Adjective-noun pairs were presented auditorily via headphones, at a comfortable amplitude. The trial did not end until a response was registered. Ten short practice trials served to adapt the subjects to the task. The stimuli used for the practice trials did not occur in the experimental trials.

\subsection{Results}

As follows from the design, the results of this experiment include the general number of correct responses as well as reaction time. In this paper, I will concentrate on the former, comparing the number of correct responses by heritage speakers to the number of correct responses by the baseline controls, and also comparing the results of this experiment to the results obtained in Experiment 1. A more detailed discussion of reaction time results and individual variation across speakers is addressed in a separate work (Polinsky in preparation).

The baseline controls gave practically error-free responses to the gender-matching and incongruous stimuli in this experiment. Figure 8 shows the responses from an individual subject, which are quite typical of the group, and Table 6 presents the average aggregate for all ten subjects. Deviations on the judgment task are negligible for the baseline controls.

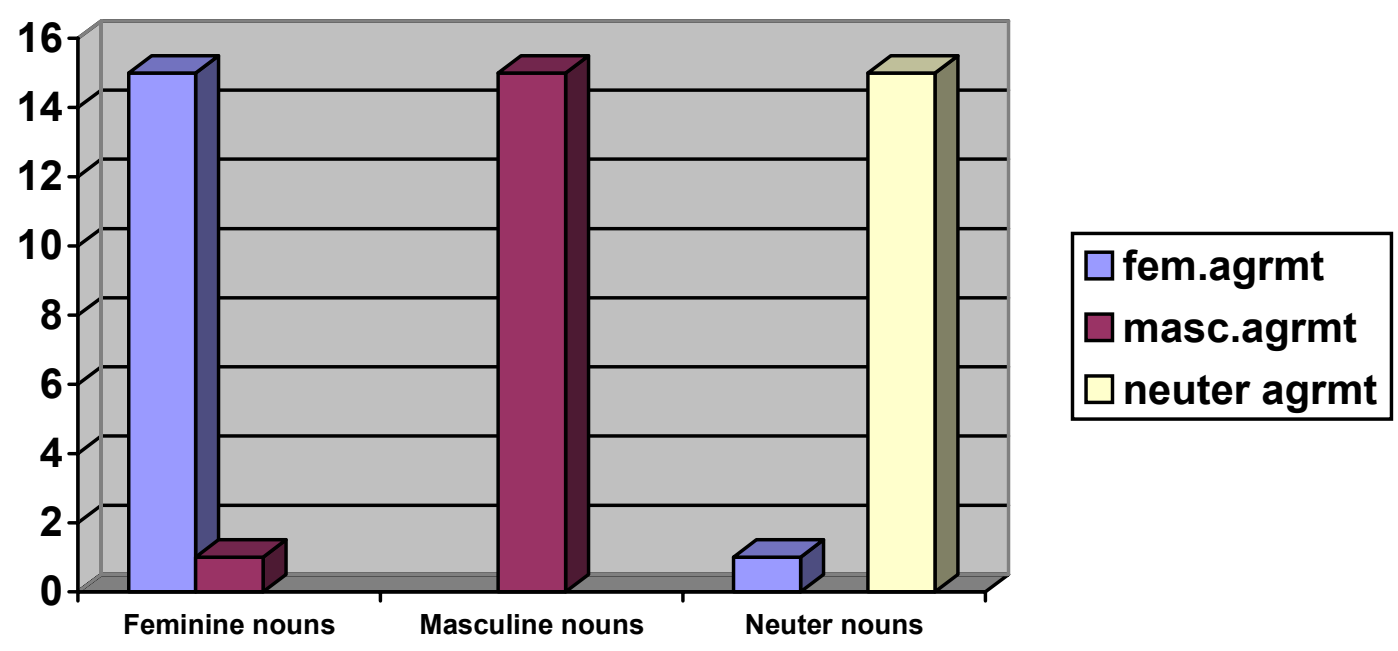

Figure 8. Judgment task responses to gender-matching and incongruous conditions, baseline speaker 
OJL.

Table 6. Correct responses on gender-matching judgment task, baseline controls (10 subjects)

\begin{tabular}{|l|l|l|l|l|}
\hline & $\begin{array}{l}\text { Masculine } \\
\text { agreement }\end{array}$ & $\begin{array}{l}\text { Feminine } \\
\text { agreement }\end{array}$ & $\begin{array}{l}\text { Neuter } \\
\text { agreement }\end{array}$ & $\begin{array}{l}\text { No } \\
\text { response }\end{array}$ \\
\hline Masculine nouns $(\mathrm{N}=15)$ & $98 \%$ & $0.5 \%$ & $1.2 \%$ & $0.3 \%$ \\
\hline Feminine nouns $(\mathrm{N}=15)$ & $1.4 \%$ & $97 \%$ & $1 \%$ & $0.6 \%$ \\
\hline Neuter nouns $(\mathrm{N}=15)$ & -- & $0.7 \%$ & $97.4 \%$ & $1.7 \%$ \\
\hline
\end{tabular}

A comparison of the aggregate results for heritage speakers shows that their performance on the judgment task is quite different (Figure 9).

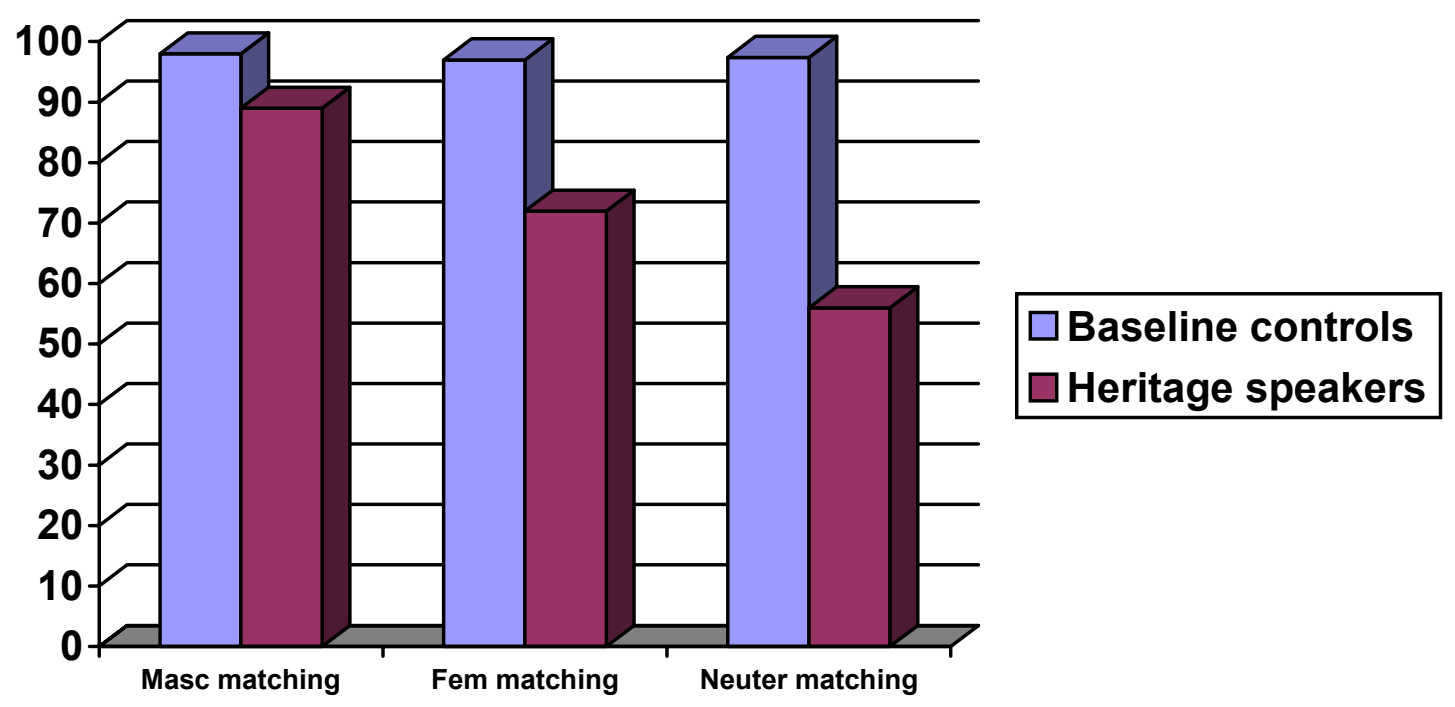

Figure 9. Percentages of correct responses on the gender-matching judgment task, averaged over all the subjects (10 baseline controls, 12 heritage speakers).

This very general comparison of the results suggests that heritage speakers still have a problem with gender assignment, although the nature of the task is different from the one in Experiment 1. While their performance on the masculine nouns is relatively close to that of the baseline controls, it is significantly lower for the feminine nouns and is at chance for the neuter nouns. 
The analysis of errors made by heritage speakers reveals interesting regularities. The overall set of errors, averaged across all the subjects, is shown in Figure 10.

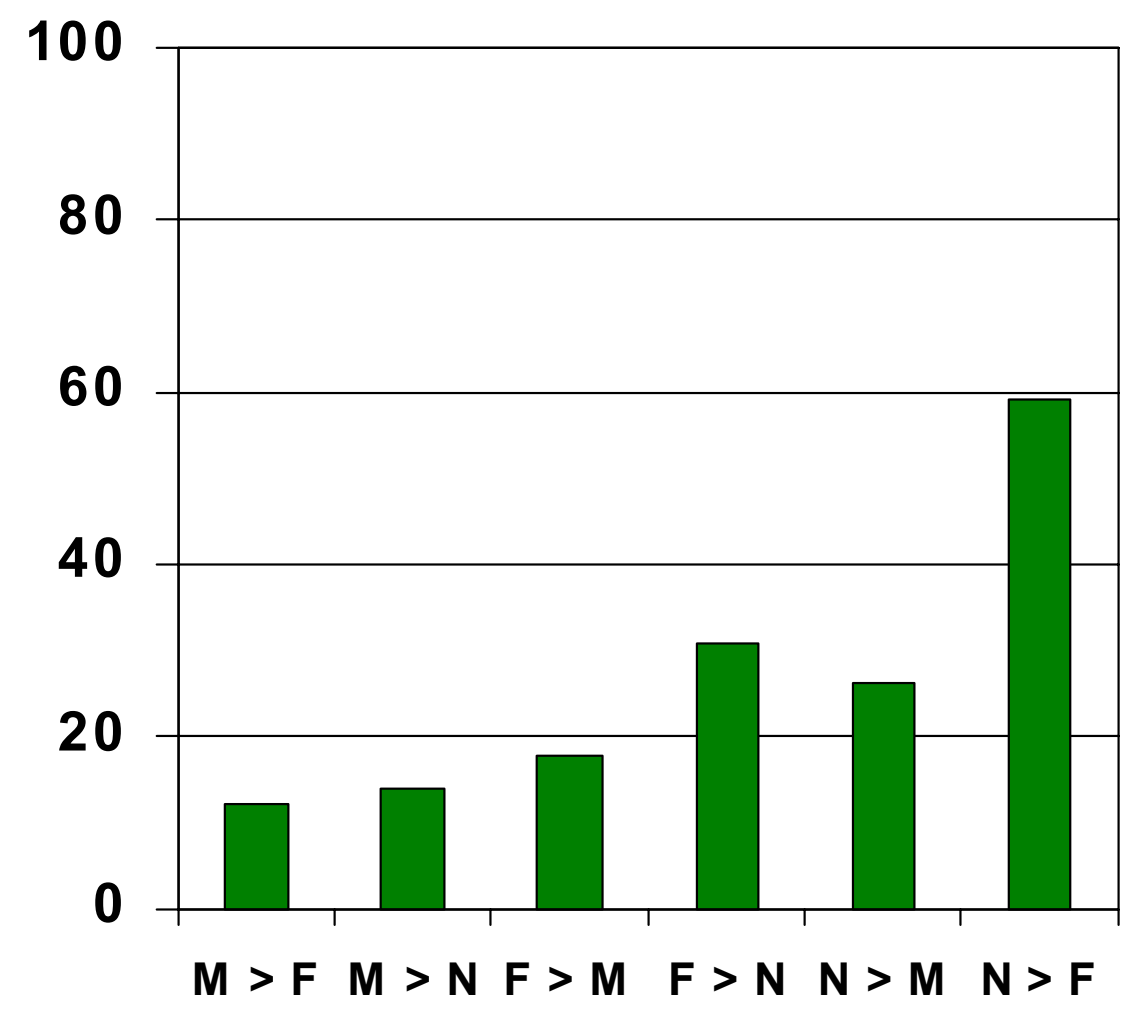

Figure 10. Percentage of errors on gender-incongruous conditions, heritage speakers only $(\mathrm{N}=12)$

It is significant that the subject accepted neuter nouns as feminines at a very high rate (almost $60 \%$ ). All other misassignments of gender occur at a much lower rate, and do not seem to show a strong pattern. If we look more closely at the errors on the neuters alone, it becomes apparent that some subjects consistently treat neuters as feminines - in keeping with the findings obtained in Experiment 1. 


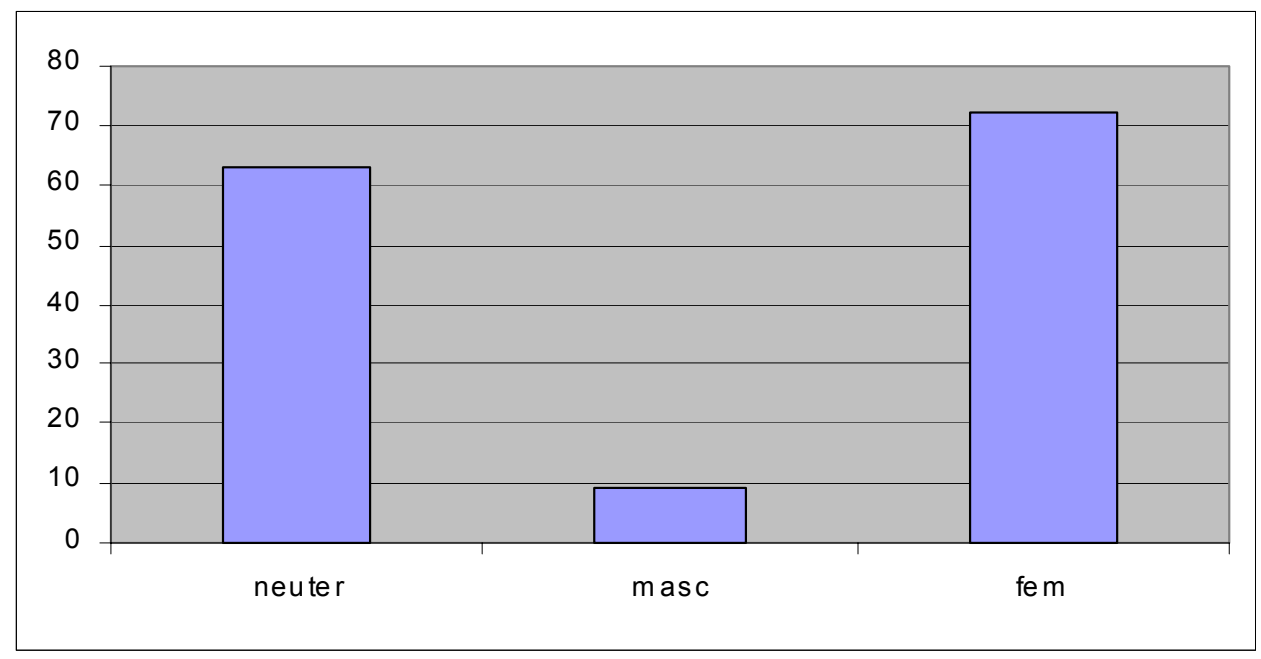

Figure 11. Performance on neuter nouns, all subjects $(\mathrm{N}=12)$

The two-gender group from Experiment 1 shows a very strong neuter-to-feminine reanalysis (almost 80\%). The three-gender group from Experiment 1 still keeps the neuter, as shown in Figure 12. To follow the results in Figure 12, recall that subjects were allowed more than one response to the stimuli, and all the responses were counted. Speaker 1 is clearly "in-between" the two-gender group and the three-gender group. The remaining speakers (2-5) perform well on the maintenance of the neuter but also show variation in response to the neuter nouns. Regardless of the reanalysis of neuters, this significant range of variation in response to judgment tasks seems to be characteristic of heritage speakers in general. It is reflected in rather high range of variation in responses to other genderincongruous conditions, as shown in Figure 10, and is crystallized in the responses to neuter nouns by the three-gender group (Figure 12). 


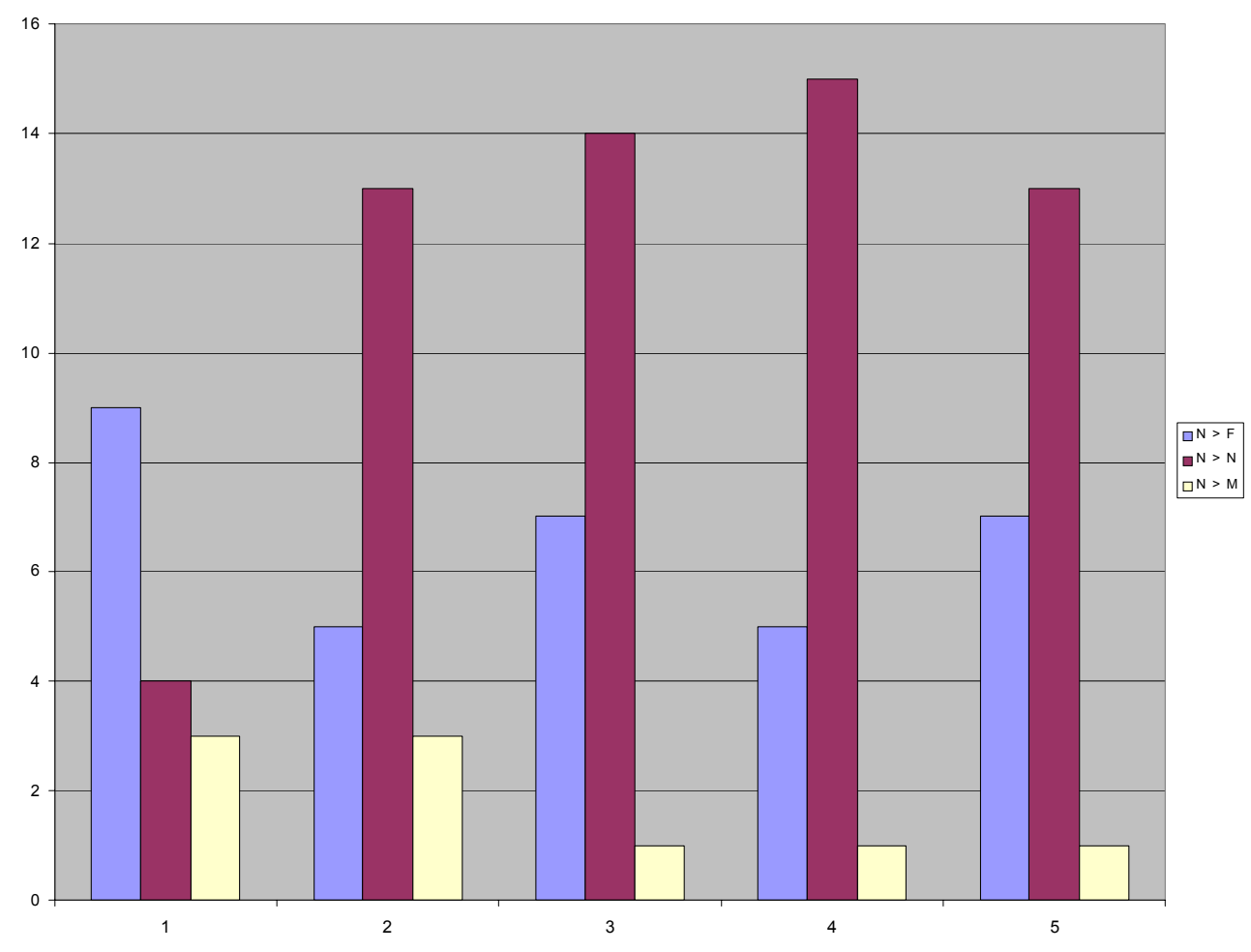

Figure 12. Performance on neuter nouns, the three-gender group $(\mathrm{N}=5)$

\subsection{Discussion}

The judgment task experiment reported in this section confirms the findings of Experiment 1: heritage speakers still fall into two separate groups, those who recognize two genders and those who keep the neuter, while still reanalyzing some neuter nouns as feminine (Figure 12). Thus, despite the difference in the nature of the task, heritage speakers' knowledge of grammatical gender can be assessed and again proves to be quite different from that of baseline speakers.

In addition to confirming the findings of Experiment 1, this experiment also shows an unexpected characteristic of heritage speakers, namely, a much greater variation than in the baseline. While the baseline speakers have no trouble separating gender-matching and gender-incongruous stimuli in this experiment, heritage speakers accept gender-matching conditions as well as some gender-incongruous ones. In a number of cases, they respond to more than one stimulus as correct, which leads to the 
generally inferior performance on forced choice. This result is consistent with prior findings (Polinsky 1997, 2000) which show that heritage speakers are often reluctant to make a choice between two or more stimuli on a judgment task, but it is the first time that impressionistic observations are actually corroborated by experimental statistics (cf. Figures 10 and 12 above). Assuming the heritage speakers' inferior performance on judgment tasks, we face the challenge of finding other experimental measures that would allow us to assess their language competence. One such measure seems to be reaction times (Polinsky 2004, in press-b; in preparation), but in addition, other measures may be needed.

\section{Conclusions}

Based on experimental data, this paper has demonstrated that heritage speakers of Russian (American Russian speakers) reanalyze the grammatical gender system in ways significantly different from the baseline. Gender assignment in the baseline crucially depends on the knowledge of the declensional system of Russian. Such knowledge is either entirely absent or seriously reduced in heritage speakers, who typically have very few cases as compared to the baseline. In the absence of declensional information, one may expect changes in the assignment of nouns to gender classes as well. One possibility is that gender could disappear as a category; this is what happens in creoles, to which heritage languages bear a striking resemblance (Polinsky 1995). American Russian, however, does not follow this route, and gender is well represented as a category. It is important to bear in mind though that gender categorization is not immediately apparent in the production data, where many agreement "errors" or mismatches may be due to on-line difficulties typically experienced by heritage speakers. Experimental results aimed at comprehension reveal gender categorization which is quite robust, albeit different from what is observed in the baseline. An important conclusion in and of itself is that heritage speakers' knowledge cannot be fully assessed via observation "in the wild" and needs to be tested and measured using more consistent methodology.

The experimental data show that in the absence of declensional information, gender assignment becomes reliant on straightforward formal cues, namely word endings in what can be identified as the citation form (the nominative in the baseline). The use of phonological cues yields a simple division of nouns ending in a consonant (masculine) vs. a vowel. Some heritage speakers treat all vowel-final nouns as a single gender (feminine), which results in a two-gender system. Other heritage speakers distinguish between neuter nouns (those ending in a stressed $-o$, thus easily differentiable from the rest of the 
vowel-final nouns) and all other nouns, which are interpreted as feminine. These speakers maintain neuter but only as a subset of neuter as represented in the baseline.

The overall reanalysis of the baseline noun categorization system by heritage speakers targets those classes that pose a challenge to L1 learners and/or are numerically smaller (neuter is the smallest gender class in the baseline), and assimilates nouns of those classes to stronger "attractors". It would be wrong, however, to equate the reanalysis of gender in American Russian to some kind of fossilization of childhood errors by L1 learners - some of the errors that occur in L1 acquisition never occur in heritage speakers, and some reanalyses by heritage speakers follow a different path compared to child language. Furthermore, no child learner starts with a two-gender system that later develops into a three-gender system, whereas some heritage speakers maintain a two-gender system. In summary, the errors made by heritage speakers overlap with the errors made by L1 learners of Russian, but are not exactly the same in nature. It is possible that heritage speakers reanalyze the system based on their limited input, and the results of this reanalysis are not the same as in emergent systems of L1 learners.

The finding that American Russian speakers divide into two distinct groups with respect to gender assignment - the two-gender group and the three-gender group — further attests to the significant variation among heritage speakers, which has been noted by many researchers. It is significant that the distribution of the two groups of speakers with respect to gender categorization is not accidental: it correlates with the general proficiency of individual speakers as measured by their overall speech rate. Heritage speakers whose speech rate is much lower than that of baseline speakers have a two-gender system, with the complete absorption of the neuter into the feminine class. Heritage speakers whose speech rate is higher maintain a reduced neuter class, hence a three-gender system. It seems likely that "slower" speakers are those whose overall proficiency is lower and it is not accidental that these speakers show a more dramatic reanalysis of the baseline than their more proficient counterparts.

Tackling the immense variation among heritage speakers is a challenging, monumental task, and if the utility of rate of speech as a general measure of a heritage speaker's proficiency can be confirmed by studies other than this one, a sensible assessment tool would be provided to both researchers and educators. Another such tool is the rate of lexical proficiency as measured by a simple wordlist test (Polinsky 1997, in press-a), which also provides a good predictive measure of heritage speaker ability. A possible combination of these two measures remains a topic of further research. 
In addition to the issue of finding independent measures aimed at heritage speakers' proficiency, a number of other outstanding questions remain. Given the difficulty of gender learning in L2, it would be instructive to investigate how heritage speakers compare to L2 learners of Russian. Such a comparison would allow us to identify those properties of noun categorization and gender priming that cut across all these groups and those that are specific to L1, L2, and to heritage speakers only.

In the study presented here, all the heritage speakers were dominant in English, which makes it difficult to separate possible interference from English and arguably universal properties of incomplete acquisition. It would take a study of gender assignment in heritage Russian with the dominant language other than English to determine what English interference amounts to. English does not have grammatical gender, ${ }^{7}$ and it would be particularly desirable to investigate noun categorization in the heritage Russian influenced by another language which has a gender system, be that a two-gender language like Romance or Hebrew, or a three-gender languagesuch as German. ${ }^{8}$

\section{References}

Ahutina, Tatiana, Andrei Kurgansky, Marina Kurganskaya, Maria Polinsky, Natalya Polonskaya, Olga

Larina, Elizabeth Bates, Mark Appelbaum. 2001. Processing of grammatical gender in normal and aphasic speakers of Russian. Cortex 37: 295-326.

Andrews, David R. 1998. Sociocultural perspectives on language change in diaspora. Amsterdam: John Benjamins.

$\mathrm{Au}$, Terry, and Janet Oh. 2005. Korean as a heritage language. In Ping Li (General Ed.), Handbook of East Asian Psycholinguistics, Part III: Korean Psycholinguistics. Cambridge: Cambridge University Press.

$\mathrm{Au}$, Terry and Romo, Laura 1997. Does childhood language experience help adult learners In Chen (ed.), The Cognitive Processing of Chinese and related Asian Languages, 417-441.Beijing: Chinese University Press.

\footnotetext{
${ }^{7}$ A study of Russian influenced by another genderless language, Finnish, also shows the retention of grammatical gender (Leisio 2001).

${ }^{8}$ All the relevant speech communities now have large numbers of heritage speakers of Russian, which makes such a study imminently possible.
} 
Berman, Ruth, and Dan I. Slobin. 1994. Relating events in narrative: A cross-linguistic developmental study. Hillsdale, NJ: Lawrence Erlbaum.

Bermel, Neil, and Olga Kagan. 2000. The maintenance of written Russian in heritage speakers. In Olga Kagan and Benjamin Rifkin, eds. The learning and teaching of Slavic languages and cultures: Toward the $21^{\text {st }}$ century, 405-436. Bloomington, IN: Slavica.

Carpenter, Kathie. 1992. Later rather than sooner: extralinguistic categories in the acquisition of Thai classifiers. Journal of Child Language 18: 19-113.

Carroll, Susanne. 1989. Second language acquisition and the computational paradigm. Language Learning 39: 535-594.

Carroll, Susanne. 1995. The hidden dangers of computer modelling: Remarks on Sokolik and Smith's connectionist learning model of French gender. Second Language Research 11: 193-205.

Cohen, Jonathan, Brian MacWhinney, Matthew Flatt, and Jefferson Provost. 1993. PsyScope: A new graphic interactive environment for designing psychology experiments. Behavioral Research Methods, Instruments, and Computers 25:257-271.

Comrie, Bernard, Gerald Stone, and Maria Polinsky. 1996. The Russian language in the twentieth century. Oxford: Clarendon Press.

Corbett, Greville. 1991. Gender. Cambridge: Cambridge University Press.

Dorian, Nancy, ed. 1989. Investigating obsolescence: Studies in language contraction and death.

Cambridge: Cambridge University Press.

Erbaugh, Mary. 2004. Chinese classifiers: Their use and acquisition. In Ping Li, Li Hai Tan, Elizabeth

Bates, and Ovid J.L. Tzeng (eds.) Handbook of East Asian psycholinguistics: Chinese. Cambridge:

Cambridge University Press.

Fenyvesi, Anna, ed. 2005. Hungarian language contact outside Hungary. Amsterdam: John Benjamins. Geisherik, Anna. 2005. Aspects of teaching literacy to heritage learners of Russian. Ph. D. Dissertation, SUNY Stony Brook.

Godson, Linda. 2003. Phonetics of language attrition: Vowel production and articulatory setting in the speech of Western Armenian heritage speakers. Ph. D. Dissertation, University of California San Diego. Gvozdev, Aleksandr N. 1961. Voprosy izučenija detskoj reči. Moscow: Izd. Akad. ped. nauk. Kagan, Olga, and Debra Friedman. 2003. Using the OPI to place heritage speakersof Russian. Foreign Language Annals 36: 536-545. 
Kagan, Olga, and Kathleen Dillon. 2001. A new perspective on teaching Russian: Focus on the heritage learner. Slavic and East European Journal 45: 507-518.

Karmiloff-Smith, Annette. 1979. A functional approach to child language: A study of determiners and reference. Cambridge: Cambridge University Press.

Leisio, Larisa. 2001. Morphosyntactic convergence and integration in Finland Russian. Ph. D.

Dissertation, University of Tampere.

Levelt, Willem J.M. 1989. Speaking: From intention to articulation. Cambridge, MA: The MIT Press.

Levelt, Willem J.M., ed. 1993. Lexical access in speech production. Cambridge: Blackwell.

Polinsky, Maria. 1995. Cross-linguistic parallels in language loss. Southwestern Journal of Linguistics 14: $87-125$.

Polinsky, Maria. 1997. American Russian: Language loss meets language acquisition. In Wayles Browne et al., eds. Formal Approaches to Slavic Linguistics, 370-407. Ann Arbor: Michigan Slavic Publications.

Polinsky, Maria. 2000. A composite linguistic profile of a speaker of Russian in the US. In Olga Kagan and Benjamin Rifkin, eds. The learning and teaching of Slavic languages and cultures: Toward the $21^{\text {st }}$ century, 437-466. Bloomington, IN: Slavica.

Polinsky, Maria. 2004. World class distinctions in an incomplete grammar. In Dorid Ravid, ed.

Perspectives on language and language development, 423-438. Dordrecht: Kluwer.

Polinsky, Maria, in press-a. Incomplete acquisition: American Russian. Journal of Slavic Linguistics.

Polinsky, Maria, in press-b. Heritage language narratives. In Donna Brinton and Olga Kagan, eds.

Heritage Languages: A New Field Emerging. Hillsdale, NJ: Lawrence Erlbaum.

Polinsky, Maria, in preparation. Gender assignment under incomplete acquisition.

Seliger, Herbert W., and Robert Vago. 1991. First language attrition. Cambridge: Cambridge University Press.

Sharoff, Sergey. 2001. The frequency dictionary for Russian.

Online version: http:/www.artint.ru/projects/frqlist/frqlist-en.asp

Sokolik, Margaret, Michael Smith. 1992. Assignment of gender to French nouns in primary and secondary language: A connectionist model. Second Language Research 8: 39-58.

Sorace, Antonella. 2004. Native language attrition and developmental instability at the syntax-discourse interface: Data, interpretations and methods. Bilingualism: Language and Cognition 7: 143-45. 
Tsimpli, Ianthi, Antonella Sorace, Caroline Heycock, and Francesca Filiaci. 2004. First language attrition and syntactic subjects. International Journal of Bilingualism 8: 257-278.

Valdés, Guadalupe. 2001. Spanish for Native Speakers. Vol. 1. New York, NY: Harcourt College Publishers.

Zaliznjak, Andrej A. 1967. Russkoe imennoe slovoizmenenie. Moscow: Nauka.

Appendix 1. Stimuli, Experiment 1

\begin{tabular}{|c|c|c|}
\hline Masculine (5.5) & Feminine (5.6) & Neuter (5.7) \\
\hline вывод & беда & белье \\
\hline выстрел & беседа & благо \\
\hline грех & волна & болото \\
\hline дворец & грязь & бревно \\
\hline замок & жертва & ведро \\
\hline запас & забота & войско \\
\hline Звонок & задача & горло \\
\hline источник & запись & дно \\
\hline корень & изба & добро \\
\hline кружок & капля & железо \\
\hline кусок & кость & занятие \\
\hline локоть & краска & звание \\
\hline мороз & лодка & золото \\
\hline огород & могила & кладбище \\
\hline отдел & морда & колесо \\
\hline песок & обида & кольцо \\
\hline подвал & одежда & крыло \\
\hline пожар & основа & крыльцо \\
\hline покой & охота & легкое \\
\hline полет & охрана & лекарство \\
\hline порей & ошибка & одеяло \\
\hline порог & палатка & озеро \\
\hline поток & печать & отличие \\
\hline предел & печка & перо \\
\hline предмет & победа & пламя \\
\hline прием & полоса & платье \\
\hline признак & польза & полотно \\
\hline размер & постель & пятно \\
\hline раствор & пуля & решето \\
\hline ремень & пыль & ружье \\
\hline рукав & рана & сверло \\
\hline слой & родина & тепло \\
\hline
\end{tabular}




\begin{tabular}{|l|l|l|}
\hline слух & скала & шоссе \\
состав & степень & яблоко \\
способ & столица & \\
срок & страсть & \\
ствол & тайна & \\
толк & ткань & \\
туман & тревога & \\
успех & труба & \\
участок & тюрьма & \\
фонарь & церковь & \\
халат & шутка & 34 words \\
храм & & \\
шепот & & \\
45 words & 43 words & \\
\hline
\end{tabular}

Appendix 2. Stimuli, Experiment 2 (15 words for each gender)

\begin{tabular}{|l|l|l|}
\hline Masculine & Feтinine & Neuter \\
\hline блеск & жалость & блюдо \\
грохот & молния & жилье \\
договор & мышца & зерно \\
доклад & оценка & копыто \\
достаток & палата & копье \\
кирпич & перемена & общение \\
наряд & поддержка & питание \\
обычай & полость & пятно \\
отчет & пустота & свойство \\
перевод & решетка & седло \\
подвиг & свеча & село \\
поцелуй & соль & сено \\
пушок & челюсть & сочинение \\
ручей & шкура & судно \\
сосуд & ярость & указание \\
& & \\
\hline
\end{tabular}

